\title{
Making a difference: The construction of ethnicity in HIV and STI epidemiological research by the Dutch National Institute for Public Health and the Environment (RIVM)
}

\author{
Alana Proctor*, Anja Krumeich, Agnes Meershoek \\ Maastricht University/CAPHRI, Department of Health Ethics and Society, 6200MD Maastricht, The Netherlands
}

\section{A R T I C L E I N F O}

\section{Article history:}

Available online 1 May 2011

\section{Keywords:}

The Netherlands

Ethnicity

HIV

STI

Migrants

Race

Epidemiology

Co-evolution

\begin{abstract}
A B S T R A C T
Biomedical and public health researchers and practitioners routinely record and comment on ethnicity: however, the use of this category is often vague and without explicit statement on what ethnicity is or how it correlates to health disparities. Presented here is an inquiry into the case of ethnicity in HIV/STI research in the Netherlands. This paper considers the construction and operationalization of the concept ethnicity in HIV/STI epidemiological research in the Netherlands. The concept ethnicity is followed as it is defined, measured, categorized, communicated and constructed in the annual national HIV/STI surveillance report of the Dutch National Institute for Public Health and the Environment (RIVM) and as this construction co-evolves in society through the Dutch media, politics and prevention practice. The epidemiological work of the RIVM on HIV/STI in The Netherlands has resulted in the materialization of a distinct ethnic construction, the high risk sexual ethnic other, presumed, not only to be at heightened risk for HIV, but also to spread HIV in the Netherlands through promiscuity and absent safe sex practices. This construct is shown to be perpetually self-validating as it informs methodological choices, such that, behavioural studies almost always establish ethnic behavioural differences. The construct and related ethnic rhetoric also allow for the extrapolation of "findings" within a specific ethnic group regarding a specific STI to all groups considered ethnic minorities and so a categorical ethnic minority problem group is constructed within Dutch society. This imagery is disseminated through newspaper articles and dialogue in the Dutch House of Representative and HIV/STI prevention practice, through which the construct is reaffirmed and ascribed scientific and social validity. Knowledge of ethnic minorities' highrisk status and their sexual practices that lead to this become common, and so the construct is further operationalized in government budget planning and subsequent research programmes.
\end{abstract}

(c) 2011 Elsevier Ltd. All rights reserved.

\section{Introduction}

In the Netherlands it is commonly stated that there exists ample evidence to show that ethnic backgrounds of certain groups hamper HIV and STI prevention, testing, and treatment. Initially, a migration linked high-risk sub-population category emerged from the 2001 HIV Surveillance Advice, a report by the Dutch Advisory Council on Health Research (RGO), requested by the Ministry of Health, Welfare and Sport on April 15, 1999. The advisory council found that little to no surveillance is conducted among migrants from areas with generalized HIV-epidemics (Rgo, 2001). Thus, in accordance with UNAIDS guidelines for HIV surveillance in areas

\footnotetext{
* Corresponding author. Tel.: +31(0)652004683.

E-mail address: alana.proctor@maastrichtuniversity.nl (A. Proctor).
}

with concentrated HIV epidemics, such as the Netherlands, the RGO recommended serosurveillance and behavioural research to be completed in migrant sub-populations. This subsequent serosurveillance and behavioural research is the object of inquiry in this paper. We follow how the category "migrants from areas with generalized HIV-epidemics" is operationalized by the main institution responsible for said serosurveillance and behavioural research in the Netherlands, namely the Dutch National Institute for Public Health and the Environment (RIVM). As shown in this paper the category evolved along the lines of ethnicity, which is a frequently used concept in biomedical and public health practices.

Most biomedical and public health researchers and practitioners routinely record and comment on ethnicity. Those critical of the use of this category argue that the use of ethnicity in practice is often vague and without explicit statement on what ethnicity is or how 
exactly it correlates to health disparities (Cho, 2006; Gravlee, 2009; Kaplan \& Bennett, 2003; Lee, 2009; Wyatt, 1991). In her 1991 paper Examining Ethnicity Versus Race in AIDS Related Research, Gail Elizabeth Wyatt eloquently outlines several concerns and warns that "the manner in which ethnic minority groups are defined and categorized can influence decisions about the context of sex related studies, data collection methods, questions that best reflect a variety of life experiences, as well as ethnic specific interpretations of the findings" (p. 37). Kaplan and Bennett (2003) indicate three specific challenges pertaining to the use of race and ethnicity in research, practice, and policy: 1 . The complexity of identity, the lack of clear-cut boundaries between categories to capture socially defined constructs of race and ethnicity, and the lack of consistency across studies and data sets in the selection and definition of categories; 2. The challenge of distinguishing between race/ ethnicity as risk factors and risk markers; 3 . The challenge to avoid contributing to racial/ethnic divisions in society (p. 2709). These authors continuously emphasize the social constructedness and dynamic nature of racial and ethnic categories by utilizing the term socially defined concepts, thus reiterating that these do not reflect a natural nor biological order. Their concerns and related recommendations address specifically mainstream biomedical and public health practitioners whom, according to the authors, must strive "to find the least imprecise way to approximate socially defined concepts of race and ethnicity for descriptive and statistical purposes" (p. 2711). Recently, the re-emergence of a biological conceptualization of race and ethnicity in genetics research has stimulated similar practical debates (Frank, 2007). Where these exceedingly technical discussions can fall short, however, is their failure to place biomedical and public health endeavours in critical social context. Or as concluded by Frank: "Perhaps, the most damning of issues facing genetic research on racial disparities in health is a failure to recognize science as a project of culture" (p.1891).

Similar yet peripheral to the more technical debates, the use of ethnicity in especially Public Health, focusing on behavioural and cultural dynamics, can also be seen to allow for unrestrained biological essentialization, ethnic stereotyping and victim blaming (Essed, 1991; Gilroy, 1987; Sinha, Curtis, Jayakody, Viner, \& Roberts, 2007; Stillwaggon, 2006). Socially constructed notions of ethnicity are enacted in science and professional practice and treated as apolitical variables, through these institutions scientific and professional merit is ascribed to analyses of these variables and factual knowledge is produced. Subsequently, these scientifically proven facts about ethnicity (and ethnic minorities) re-enter society where they further evolve and can perpetuate categorical systems of difference (Meershoek \& Krumeich, 2009; Meershoek, Krumeich, \& Vos, 2007; Meershoek, Krumeich, \& Vos, 2011; Shim, 2002; Stillwaggon, 2006). Such co-evolution between scientific and professional practice and society is the object of inquiry in science and technology studies (Jasanoff, Markle, Petersen, \& Pinch, 1995; Latour, 1988).

Science and technology studies consider professional practices as practices in which complex realities are reduced to simple understandable orders through the use of ordering instruments such as styles, discourses, logics, scripts, and so on. Reality, in other words, is enacted in scientific and professional practices as a result of attempts to deal with complexity and is considered to be the product of these scientific and professional ordering processes (Berg \& Mol, 1998; Law, 1994; Law \& Mol, 2002). These activities, however, do not only produce a factual reality, normative orders appear during this process as well (Berg \& Mol, 1998). Characteristics are ascribed to the ordered elements, shaping their possibilities as well as their boundaries for agency. Consequently, this process is by no means socially, politically or normatively neutral.
Norms and assumptions that are acted out in scientific and professional practice and norms and assumptions underlying scientific research and practice are validated as consequence of this enactment and then fed back into society. Scientific and professional practices all enact (and validate) versions of reality that intervene in the world (Moser, 2006). It follows that scientific and professional sites have been established as sites of social and political negotiation, where socially problematic concepts - such as "race", "ethnicity", and "gender" are worked out in practice (Epstein, 2007; Schulz \& Mullings, 2006). The science and technology studies perspective does not presume that realities are given, definite, "discoverable" nor independent of our accounts and representations of them, but rather, emerge in specific material practices and locations and find their way into society and visaversa. Shim (2002) commenting on the use of race, socioeconomic status (SES) and sex in epidemiology concludes: "Causal links are seen as multi-directional: socio-cultural contexts influence scientific knowledge production, and technoscientific projects construct social reality. That is, practices around the inclusion of race, SES and sex in epidemiological research are both the products of and contributors to the larger social order", or plainly, what is selected to be counted and how these selected elements are counted matters, as this process is constitutive to shaping knowledge and society (p.144).

This paper considers the construction and operationalization of the concept ethnicity in HIV and STI epidemiological research in the Netherlands. The concept ethnicity is followed as it is narrated, defined, measured, categorized, communicated, constructed in the work of the Dutch National Institute for Public Health and the Environment (RIVM) and as it evolves in society through the media, politics and prevention practice.

\section{Methodology}

Since 1995 STIs are registered into an STI registration at the RIVM in the Netherlands. In 2003, an STI sentinel surveillance system was launched, which reached national coverage in 2004 with inclusion of all major national STI centres. All consultations and corresponding diagnoses are reported online to the RIVM's Centre for Infectious Disease Control (CIb) for surveillance purposes and published in an annual report. In 2006 a limited set of behavioural indicators was added to the STI surveillance system.

Findings presented in the first section of this paper are based on a content analysis of the national STI and HIV surveillance reports published by the RIVM between 2005-2009 (RIVM, 2006a, 2007b, 2008, 2009). In 2005 and 2008 the RIVM report refers directly to national surveillance data published previously or separately, these five documents, three city-surveys in 2005 and one in 2007 and a separate behavioural publication in 2008 , all written in Dutch, were also included in analysis (de Boer-van der Kolk, van de Laar, \& Op de Coul, 2009; RIVM, 2005a, b, 2006b, 2007a, b). These annual reports were selected for analyses of epidemiological research on HIV and STI as the RIVM is the national institution responsible for producing official epidemiological data for the Netherlands, and is thus the authority in this area in the Netherlands. Accordingly, these annual reports represent the official annual statistics utilized and recognized by the Dutch government and internationally by organizations such as UNAIDS.

The content analysis focuses on how ethnicity is constructed and when, how and where this concept emerges. Specifically we examine ethnicity related problem definitions, data collection and the interpretation of epidemiological results. The annual reports were read chronologically and in their entirety and all passages discussing one or more of the following terms (or derivatives of) were selected for analysis: minority, ethnicity, migrant, immigrant, 
allochthonous (meaning non-native Dutch or non-Western in the Netherlands, a term often used to indicate "ethnicity"). Thus, within the RIVM's serosurveillance and behavioural research, we look at what is counted and how this is counted, and how the figures produced are interpreted and utilized further. These selected passages are analysed chronologically, as to provide a description of how ethnicity is conceptualized and operationalized in each annual report, and how this evolved through time.

The second section of this paper presents the dissemination of the data and knowledge produced by the RIVM in media, politics and prevention practice. Structured searches using the search terms RIVM and HIV, minority, ethnicity, migrant, immigrant, allochthonous or AIDS were entered in the LexisNexis ${ }^{\circledR}$ database for Dutch newspapers (which includes the five premiere national Dutch newspapers), analysis was limited to articles directly citing the RIVM reports and publications analysed in section one of this paper. While many articles made use of the information provided by these reports, three articles explicitly and directly discussed the RIVM reports. Newspapers were selected for analysis of the dissemination in media as $68.3 \%$ of the Dutch population over the age of thirteen reads a newspaper daily (Nationaal Onderzoek Multimedia, 2010). And although televised news and radio might also have been used, these formats are less likely to provide information on their sources and thus establishing a direct link to the RIVM annual reports would have been difficult.

To explore the dissemination on the data and knowledge produced by the RIVM in Dutch politics, a structured search was performed on the Dutch House of Representatives online archive using the search terms RIVM and HIV, minority, ethnicity, migrant, immigrant, allochthonous or AIDS, and again only items directly citing the RIVM reports and publications discussed in section one of this paper were included for analysis. The Dutch House of Representatives online archive was selected to explore the dissemination of the data and knowledge produced by the RIVM in Dutch politics, as this is the body in which ministers are obliged to answer parliamentarians questions, in this case the minister of Health, Welfare and Sport about health and disease trends.

And finally, examples of HIV and STI interventions targeting ethnic minorities were generated from the 2006 publication SOA en HIV/AIDS-preventie onder etnische minderheden in Nederland. Een kritische analyse van 'best practices' vanuit een evidence-based perspectief, a report commissioned by The National Institute for STI and AIDS Control in the Netherlands (STI AIDS Netherlands) to evaluate the national best-practices for prevention among ethnic minorities (Vrolings, Gelissen, Jonkers, \& Schaalma, 2006). This report was selected, as it is an overview of the HIV and STI interventions targeting ethnic minorities considered "best practices" in the Netherlands.

\section{RIVM annual HIV and STI surveillance reports 2005-2009}

In this first section, we follow the development and evolution of the operationalization of the category "migrants from areas with generalized HIV-epidemics" in the work of the RIVM from 2005-2009. The annual reports are discussed and analyzed in chronological order.

\section{5: migrants from HIV endemic countries}

The data and conclusions presented in the 2005 RIVM annual report are based on three HIV-surveys of high-risk groups in Amsterdam $(n=668)$, Rotterdam $(n=592)$ and The Hague ( $n=1039$ ) (RIVM, 2005a, b, 2006b). The category "migrants" is used here and labelled "high-risk" and the category is cited to be derived directly from the recommendation of the Dutch Advisory Council on Health Research, thus "migrants from areas with generalized HIV-epidemics". All three surveys are titled "HIV-surveys by high risk groups in [city]" and were conducted over a period of one year by the RIVM in coordination with the local municipal health services (GGDs). The term "migrant" was defined as a person who was him/herself or at least one of the parents born in Suriname, the Dutch Antilles, Aruba or any African country south of the Sahara. In the 2005 RIVM report, data was grouped according to four ethnic categories: Surinamese, Antillean, Ghanaian or Cape Verdean. Data was presented in nine groups (Surinamese in Amsterdam, Rotterdam, and The Hague; Antilleans Amsterdam, Rotterdam, and The Hague; Cape Verdeans in Rotterdam; and Ghanaians in Rotterdam and the Hague). Of these nine groups, three had a reported HIV prevalence of 0\% (Surinamese in Amsterdam, Antilleans and Arubans in Amsterdam and Rotterdam), and the other groups ranged from $0.6 \%$ to $1.8 \%$.

All three of the RIVM city reports conclude by stating the potential risk the high-risk migrant group poses to the general population and by stating that sexual risk behaviour is "high" among migrants (RIVM, 2005a):

There is a potential for HIV and STI transmission from high risk groups into the general population in the Netherlands...Considerable sexual risk behaviour is reported in the migrant groups, more by men than by women: many sexual partners, concurrent partnerships and a low rate of condom use with steady and casual partners. Nine to sixteen percent of the migrants reported unsafe sex contacts with at least two partners in the previous six months. (RIVM Amsterdam, 2005, p. 3).

Because of how the category "migrants from areas with generalized HIV-epidemics" is defined in these surveys, the definition presents persons of any Dutch Caribbean or sub-Saharan African heritage (even when born and permanently residing in the Netherlands) as a possible bridge between HIV at "home" and the Netherlands. And so, here the RIVM inserts a causal link between ethnicity and HIV that in not based necessarily on one's actual proximity to areas with generalized HIV endemics, but rather on one's ethnicity. Furthermore, this causal relationship is presented to be the result of increased sexual risk behaviour among ethnic groups, and not actual proximity to an area with a generalized HIV endemic. Along with sex workers and their clients, migrants are categorized here as a high-risk population that the general Dutch population is to be protected from. These conclusions and the assigned high-risk status are cited as based on findings of 1) increased prevalence of HIV within this sub-population in the Netherlands and 2) high sexual risk behaviour. Two critical observations can be made here, regarding narrative and methodology.

Firstly, regarding narrative, the 2005 annual RIVM report andcity survey references four nationalities: Cape Verdeans, Surinamese, Antilleans and Ghanaian. The conclusions, however, are extrapolated to all migrant and ethnic groups. The language and terms used in direct reference to the results of the three city surveys and annual report speaks of "migrants", "migrant groups" and "ethnic groups". Consequently, an ethnic problem group appears along with a causal link between ethnicity and HIV - regardless of an actual increased prevalence as one-third of these reported groups have a prevalence of $0 \%$. Thus the original category "migrants from areas with generalized HIV-epidemics", was operationalized to refer to a more generalized group migrants or ethnic minorities. Additionally, the risk factor, high-risk sexual behaviour, has been attached to the risk factor initially ascribed to this group, namely, proximity to an area with a generalized HIV-epidemic.

Secondly, regarding methodology, this research does not include a non-migrant and/or general Dutch population, and so, comparisons regarding the differences between ethnic groups and the 
non-migrant and/or general Dutch population are problematic. The claim that sexual risk behaviour is higher becomes questionable when looking at the actual comparison made. All three studies conclude with findings such as "the sexual risk behaviour among migrants is high" and "condom use is low with fixed and loose partners, both for men and women. 9-16\% of the migrants has had unprotected sex contacts with at least two partners in the previous six months" (RIVM, 2005a, p.35). However, as the data is not compared to a "non-migrant" population in the same setting (age, urban setting, recruitment location, payment for participation etc), the findings regarding migrants and their higher sexual risk behaviour as presented in these studies can be disputed. As shown later in this text, methodological choices such as group categorization and data comparison in RIVM research can be problematized on several grounds.

With these surveys in the 2005 RIVM annual report, the RIVM presents migrant groups and ethnic minorities as sexually high-risk and high-risk for transmitting HIV to the general Dutch population. An association is made here between risk behaviour, ethnicity and HIV even for populations where the prevalence is zero. This illustrates that the perceived risk category moved away from HIV prevalence in migrant populations from areas with generalized HIV-epidemics and toward ethnicity in itself, mediated by ethnically determined sexual behaviour. The locus of the problem is thus placed within these groups and more importantly within the characteristics ascribed to those deemed members of these groups. This is also visible in the renaming of the chapter from "Migrant Populations" in the 2005 annual RIVM report to "Ethnic Minority populations" in the following reports. The term migrant (group) is used interchangeably with ethnic (group), this particular construction of ethnic as synonymous to migrant allows for the linking of the original risk factor (migration from an areas with a generalized HIV-epidemics) with the risk marker ethnicity. Thus the risk factor is seen as embodied in one's ethnicity, regardless of actual migration history. The following paragraphs illustrates how despite disproving data in 2006 and 2007, this conflation of ethnic with migrant, and the associated risks, produced a specific ethnicized risk profile and allowed for specific methodological choices.

\section{6/2007 no difference}

In 2006, with the implementation of behavioural indicators in the RIVM's national surveillance system, a national comparison including all ethnicities (including Dutch) routinely occurred. Subsequently, in $2006(n=68.977)$ and $2007(n=78.062)$ the RIVM states: "No significant differences are reported in condom use at most recent sexual contact and median number of partners in the previous six months between autochthonous Dutch and other ethnicities" (RIVM, 2007b, p.75). Furthermore, the increased prevalence of some STIs among some ethnic minorities is explained with an understanding of various possible non-behavioural risk factors. The RIVM indicated that in those cases the ethnic minority patients visiting the STI centres might not represent their category accurately, "it is not clear if the group visiting the STI centres is a subgroup at higher risk than the rest of the Surinamese/Antillean people" (RIVM, 2007b, p.75). And finally the 2006 and 2007 RIVM reports clearly state that "behavioural data in ethnic groups showed that the rate of partner change reported were not higher in the ethnic groups with higher STI rates mentioned above: people from Europe (other than Eastern Europe) had the highest rates, with 34\% reporting six or more partners in past six months" (RIVM, 2007b, p.75). These 2006 and 2007 RIVM data and conclusions challenge the presumption that "ethnic minorities" are a sexual high-risk group, and show that when all ethnicities are included in a survey no sexual behavioural differences are found.

\section{Problem ethnic minorities}

Although no differences in behaviour were reported, the 2006 and 2007 reports do conclude with: “..previous positive STI diagnoses was significantly higher among Surinamese and Antillean migrants. Moreover, higher positivity rates of certain STI are found in specific ethnic groups, pointing to the need for targeted intervention by risk profile" (RIVM, 2007b, p.75). This RIVM recommendation to target ethnic minorities by their specific "risk profile" seems to have been continued to be operationalized as the high sexual risk profile, rather than migration from an area with a generalized HIV-epidemic. Thus here, the specific concept of ethnic minority as synonymous with migrant allows the high-risk status to be ascribed to ethnic minority groups, however the riskfactor (migration from an area with a generalized HIV-epidemic) is not ascribed necessarily to ethnic minorities and rather is replaced with the notion of different and specific ethnic sexual risk behaviour.

In 2007, referring directly to the RGO report (2001) discussed previously in this paper, the RIVM published a new HIV-survey in Rotterdam ( $n=1129)$, to once again investigate HIV prevalence and risk among high-risk groups. In providing the premise for this research among Cape Verdeans, Surinamese, Antilleans in Rotterdam the RGO report is referenced directly, namely, the advice to conduct surveillance of HIV among migrants from areas with generalized HIV-epidemic. Thus the risk-group label is applied however the risk-factor, migration from an area with a generalized HIV-epidemics, is replaced with high-risk sexual behaviour. The survey includes detailed questions about the number of simultaneous sexual partners and their ethnicities, condom use with various partners, knowledge of transmission and protection, sex in country of origin. The survey's two primary conclusions state that migrant groups report more simultaneous sexual partners and less condom use (RIVM, 2007a). Two critical observations can be made here.

Firstly, the terms migrant groups and ethnic groups are used interchangeably. This allows the researchers to present migrant groups as an established high-risk group while actually researching ethnic minorities. Thus, although the term migrants appears to focus on the original risk group, namely, migrants from areas with generalized HIV-epidemics, the inclusion criteria utilized in this research focus not on migration history but ethnicity, and the riskfactor focuses on sexual behaviour by ethnicity and not proximity to an area with a generalized HIV-epidemics. The inclusion criteria utilized state that minimally one parent or the respondent must have been born in Suriname, the Dutch Antilles or on Cape Verde. In this research $48 \%$ of Cape Verdeans, $44 \%$ of Surinamese and $22 \%$ of Antilleans respondents were born in the Netherlands and thus never migrated, and of those born abroad the median number of years of residence in the Netherlands was 20 years for Cape Verdeans, 22 years for Surinamese and 16 years for Antilleans. When these figures are viewed in light of the median ages (Cape Verdean: 24 years of age, Surinamese 26: years of age, and Antillean: 29 years of age), one can conclude that those who did migrate did so at a young age. Furthermore, although information on migration history and sexual activity in country of origin were collected in the survey, these are not presented in the conclusions, illustrating that the original migration related risk-factor is effectively replaced by an ethnicized sexual risk characteristic.

And secondly, what we see here is that a small urban population with a median age between 24-29 recruited at specific social locations such as festivals, night clubs, gyms, markets and community centres are compared to national data. This national figure includes data from all ages, regions and was collected in a health care setting. Yet, the differences in sexual risk behaviour as 
found in these studies are attributed to ethnicity. However, plausibly correcting this data for setting (urban), age (young: 24-33) and recruitment location might have led to other conclusions regarding differences in sexual behaviour by ethnicity. As seen in 2006 and 2007 in the national RIVM survey, when all ethnicities are included in the study populations no significant differences are found between the various groups. By making these methodological choices researchers report more unprotected sexual contact with casual partners among ethnic minorities without actually providing comparative data to constitute a statistically significant difference. In doing so, the image of a sexually high-risk ethnic other firmly materializes. These reifications of the sexually high-risk ethnic other bestow scientific and professional merit to the construct and highlight statistical and epidemiological "facts" while obscuring the rhetorical and normative assumptions underlying and premise of this research. And so by 2007 the category "ethnic minorities", previously "migrants from areas with generalized HIV-epidemics", along with injecting drug users, MSM and prostitutes had been established as a categorical high-risk group due to their supposed high-risk sexual behaviour.

\section{The high-risk sexual other}

The notion that ethnic minorities' sexual behaviour is specifically high risk seems particularly dominant. The origins of the ethnic sexual otherization in HIV and STI epidemiological research in the Netherlands are hitherto unclear, however placing this specific image in larger socio-historical context provides relevant insights. The work of the RIVM constructs ethnic minorities as sexually promiscuous and sexually unsafe. The ethnic sexual excess rhetoric also exists in HIV practices outside of the Netherlands. In the United States, "ethnic minority women are further subject to sexualized stereotypes, a phenomenon described as sexual racism. These stereotypes cast African American women as promiscuous and/or Latinas as sexually available and desirable" (Collins, von Unger, \& Armbrister, 2008). The authors argue that these "potentially stigmatizing identities influence both the way women's sexuality is viewed and their risk for HIV infections" (p. 389). In Australia, Persson and Newman (2008) assert that public health emphasis on the mutual responsibility of both partners to prevent HIV infection is undermined when "coverage of the idea of criminal intent converges with the symbolic weight of black sexuality and monsterisation is intensified as media coverage taps into the mythical hyper-sexualisation of Black men" (p. 632). Dating back to European colonisation, sexuality has been a chief differentiating mechanism (Essed, 1991; Gilroy, 1987; Hooks, 1992; Sinha et al., 2007; Stillwaggon, 2006). In her account of everyday racism in the Netherlands and the Unites States, Phillomna Essed (1991) highlights the myth of sexual pathology in the Netherlands: "The idea of Black sexuality as pathological is well implanted in European and U.S. consciousness. Nineteenth- and early twentiethcentury attempts to prove that Blacks are inherently different than Whites rested largely on sexuality" (p. 250). Thus here, thinking of science as a cultural project, invoking its historical, political, social, economic and most important complex context, calls into serious question the use of the sexualized concept of ethnicity in health research in the Netherlands.

\section{8: interchanging concepts/groups + explanatory dominance $=$ self-validation}

By 2008 ethnicity is firmly established as a categorical risk factor, due specifically to the "documented" high-risk sexual behaviour of ethnic minorities. Thus the "default" understanding for the collection and interpretation of data is that of the ethnic sexual risk behaviour. This, due to the vague, inexact and multiform conceptualization and use of the concepts ethnicity and migrant, almost always allows for the re-validation of the high-risk ethnic sexual behaviour construct with "hard facts" and so this has become a self-validating mechanism. The 2008 RIVM report and its supplemental behavioural data publication illustrate this selfvalidating process due to, firstly, the explanatory dominance of the high-risk ethnic sexual behaviour construct, and secondly, the woolly use of concepts and categories.

In 2008 no behavioural data was included in the national RIVM report, but rather published in a separate article. This separate publication is an epidemiological study of the behavioural data collected within the national surveillance system in 2008. In the separate publication, data is presented on the three behavioural questions included in the national surveillance system: a. the number of partners in the last six months, b. condom use at last sexual intercourse and c. sexual contacts abroad in the last three months. In analyses the questions were stratified for several categories: gender, ethnicity, commercial sex work, client of commercial sex work, and sexual preference. When reviewing the study design and analysis techniques, it becomes apparent that several methodological choices are made based on the high sexual risk ethnic image. The report concludes by stating that the results show that certain groups such as, MSM, prostitutes, clients of prostitutes and ethnic minorities have high-risk behaviour, more partners, a higher percentage of unprotected sex abroad and a lower percentage of condom use at last sexual contact (de Boervan der Kolk et al., 2009, p. 39). These conclusions do not necessary follow from the raw data (see Table 1), but are rather the result of the choices made in analyses and interpretation. All ethnicities other than Dutch are collated, presumably this methodological choice is the result of the dominance of the ethnic discourse in the work of the RIVM. When all ethnicities other than Dutch are lumped together, the average of this group is higher and so the conclusion regarding ethnic minorities is made. However, in the absence of a dominating ethnicity focused perspective, this data could have been interpreted differently. For example, for the category number of partners in the last six months the median is 2 across all ethnic groups. The averages however are lower for some ethnic minority groups and higher for others, where eastern Europeans are highest with an average of 28.6 sexual partners in the last three months. This 28.6 figure is not corrected for commercial sex work, ostensibly a significant determinant of this figure. And so when all ethnic minorities are lumped together without correction for other possible contributing factors, the high sexual risk ethnic minority group indeed appears. This illustrates the self-validating process that occurs when various ethnic minorities and the associated epidemiological data and associated risk factors are pooled and interchanged, and when data is extrapolated from a specific ethnic or migrant group to all groups considered ethnic minorities or migrants. Contrarily, when one looks at the data in this report on the traditional ethnic risk groups focused on in most Dutch HIV and STI research, specifically Surinamese and Dutch Antilleans, it becomes apparent that risk behaviour among these groups as determined by the three behavioural indicators does not differ much if at all from the general Dutch population. Condom use at last sexual contact was higher for Surinamese and Antillean respondents in comparison to the general Dutch population. Likewise, number of partners in the last six months was lower for Surinamese and Antillean respondents than for the general Dutch population. And so, the conclusion of the 2008 RIVM report, namely that "ethnic minorities have high risk behaviour", especially when considering that the term ethnic minority is often interpreted as Afro-Caribbean in this context, is highly problematic. 
Table 1

2009 RIVM behavioural survey data.

\begin{tabular}{|c|c|c|c|c|c|c|c|c|c|c|c|c|}
\hline & \multirow{2}{*}{\multicolumn{2}{|c|}{$\begin{array}{l}\text { Number of } \\
\text { partners last } 6 \\
\text { months: } \\
\text { average and } \\
\text { median }\end{array}$}} & \multicolumn{2}{|c|}{$\begin{array}{l}\text { Condom use at } \\
\text { last contact: } \\
\text { total and\% }\end{array}$} & \multicolumn{2}{|c|}{$\begin{array}{l}\text { Sexual contact } \\
\text { abroad: total } \\
\text { and \% }\end{array}$} & \multicolumn{2}{|c|}{$\begin{array}{l}\text { Previous HIV } \\
\text { test: total and \% }\end{array}$} & \multicolumn{2}{|c|}{$\begin{array}{l}\text { Previous } \\
\text { positive HIV } \\
\text { test: total and } \\
\%\end{array}$} & \multicolumn{2}{|c|}{$\begin{array}{l}\text { Previous STI: } \\
\text { total and \% }\end{array}$} \\
\hline & & & & $\%$ & & $\%$ & & $\%$ & & $\%$ & & $\%$ \\
\hline Total & 4.5 & 2 & 8032 & 23 & 2647 & 8 & 14987 & 37 & 386 & 1 & 6935 & 17 \\
\hline Male & 3.9 & 2 & 4502 & 26 & 1582 & 9 & 7766 & 39 & 365 & 2 & 3615 & 18 \\
\hline Female & 5.1 & 2 & 3527 & 20 & 1064 & 6 & 7216 & 35 & 21 & 0 & 3317 & 16 \\
\hline Transgender & 118.2 & 2 & 3 & 27 & 1 & 9 & 5 & 42 & 0 & 0 & 3 & 25 \\
\hline Heterosexual male & 2.8 & 2 & 3191 & 24 & 1215 & 9 & 4686 & 31 & 13 & 0 & 2002 & 13 \\
\hline Homosexual male & 7.9 & 3 & 1039 & 32 & 297 & 9 & 2513 & 67 & 331 & 9 & 1383 & 37 \\
\hline Bisexual male & 6.7 & 3 & 261 & 30 & 66 & 7 & 543 & 53 & 16 & 2 & 223 & 22 \\
\hline \multicolumn{13}{|l|}{ Client prostitute male } \\
\hline Current & 5.1 & 3 & 438 & 39 & 251 & 22 & 527 & 41 & 2 & 0 & 237 & 19 \\
\hline Past & 3.7 & 2 & 313 & 28 & 112 & 11 & 538 & 44 & 8 & 1 & 272 & 22 \\
\hline Never & 3.8 & 2 & 3679 & 25 & 1188 & 8 & 6535 & 39 & 339 & 2 & 3031 & 18 \\
\hline \multicolumn{13}{|l|}{ Prostitute female: } \\
\hline Current & 106.5 & 40 & 553 & 39 & 58 & 4 & 1437 & 69 & 2 & 0 & 506 & 24 \\
\hline Past & 9.2 & 1 & 31 & 18 & 7 & 4 & 142 & 71 & 0 & 0 & 91 & 46 \\
\hline Never & 2.1 & 2 & 2912 & 19 & 992 & 6 & 5559 & 31 & 19 & 0 & 2682 & 15 \\
\hline \multicolumn{13}{|l|}{ Ethnicity ${ }^{\mathrm{a}}$ : } \\
\hline Netherlands & 4.1 & 2 & 6707 & 23 & 2177 & 7 & 12227 & 35 & 325 & 1 & 5570 & 16 \\
\hline Turkey & 3.0 & 2 & 73 & 23 & 28 & 9 & 111 & 34 & 2 & 1 & 67 & 20 \\
\hline Morocco & 5.6 & 2 & 84 & 24 & 27 & 8 & 117 & 31 & 2 & 1 & 60 & 16 \\
\hline Suriname & 2.8 & 2 & 246 & 26 & 47 & 5 & 432 & 44 & 8 & 1 & 342 & 35 \\
\hline Ned. Antilles & 3.6 & 2 & 162 & 24 & 37 & 6 & 331 & 46 & 7 & 1 & 250 & 35 \\
\hline East-Europe & 28.6 & 2 & 91 & 28 & 35 & 10 & 282 & 61 & 2 & 0 & 108 & 23 \\
\hline Sub-Sah. Africa & 5.8 & 2 & 124 & 23 & 56 & 10 & 287 & 47 & 7 & 1 & 117 & 19 \\
\hline Latin America & 6.6 & 2 & 96 & 30 & 27 & 8 & 226 & 57 & 8 & 2 & 73 & 18 \\
\hline Other. Europe & 15.0 & 2 & 273 & 33 & 122 & 15 & 636 & 57 & 14 & 1 & 194 & 17 \\
\hline Asia & 4.8 & 2 & 108 & 21 & 59 & 11 & 218 & 38 & 8 & 1 & 107 & 18 \\
\hline Unknown & 8.8 & 2 & 44 & 20 & 13 & 6 & 77 & 35 & 2 & 1 & 35 & 16 \\
\hline Other & 3.3 & 2 & 24 & 30 & 19 & 25 & 43 & 51 & 1 & 1 & 21 & 25 \\
\hline HIV positive & 22.2 & 3 & 31 & 30 & 6 & 5 & 68 & 57 & 0 & 0 & 57 & 48 \\
\hline HIV negative & 4.9 & 2 & 5790 & 24 & 1839 & 8 & 10367 & 37 & 7 & 0 & 4289 & 15 \\
\hline Gonnarea positive & 11.2 & 3 & 175 & 23 & 85 & 11 & 488 & 57 & 84 & 10 & 344 & 40 \\
\hline Gonnarea negative & 4.5 & 2 & 7357 & 23 & 2456 & 8 & 13535 & 36 & 289 & 1 & 6261 & 17 \\
\hline Early syphilis positive & 11.2 & 3 & 87 & 25 & 35 & 10 & 263 & 68 & 70 & 18 & 192 & 50 \\
\hline Early syphilis negative & 4.7 & 2 & 7219 & 23 & 2357 & 8 & 13014 & 36 & 263 & 1 & 5959 & 17 \\
\hline Chlamydia positive & 4.9 & 2 & 655 & 18 & 268 & 7 & 1355 & 32 & 70 & 2 & 891 & 21 \\
\hline Chlamydia negative & 4.6 & 2 & 6884 & 24 & 2275 & 8 & 12670 & 37 & 305 & 1 & 5721 & 17 \\
\hline Never HIV test & 2.9 & 2 & 4330 & 21 & 1480 & 7 & Nvt & & Nvt & & 2103 & 9 \\
\hline Past positive text & 11.5 & 4 & 115 & 35 & 40 & 11 & Nvt & & Nvt & & 289 & 75 \\
\hline Past negative test & 7.1 & 2 & 3428 & 28 & 1036 & 8 & Nvt & & Nvt & & 4238 & 29 \\
\hline Past unknown & 4.3 & 2 & 33 & 21 & 18 & 11 & Nvt & & Nvt & & 47 & 24 \\
\hline HIV test unknown & 5.0 & 2 & 126 & 10 & 73 & 6 & Nvt & & Nvt & & 258 & 16 \\
\hline
\end{tabular}

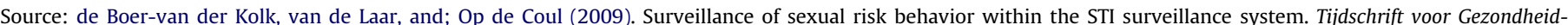
swetenschappen (1), 37-41.

a As indicated by client.

\section{Practice, policy and media}

The effect of the work of the RIVM is extensive. As the national authority in this realm of research, the RIVM is widely cited in academic and public research, prevention programming, politics and the media. The RIVM surveys and reports discussed above were directly cited in the Dutch parliament, prevention practices and the media. Consequently, the construct of ethnic minorities as a highrisk sexual ethnic other has been widely absorbed in prevention practice, politics and the media.

Copious sexual behaviour change programmes have been developed especially for ethnic minorities:

1. Voorlichting aan Afrikanen Utrecht (Health Education for Africans in Utrecht)
- Goal: To increase safe sex practice among ethnic minorities. To increase HIV/STI/Safe sex knowledge.

- Method: Educational sessions at African socializing locations and condom distribution.

2. Uma Tori!

- Goal: Increase empowerment and "healthy" sexual relationships for Antillean, Aruban and Afro-Surinamese women 17-45.

- Method: Information sessions.

3. Safe Sex Party Antilliaanse Jongeren (Safe Sex Party Antillean Youth)

- Goal: Improve safe-sex norm among Antillean youth.

- Method: Football tournament and safe-sex party (during which condoms were distributed and application demonstrated, safe sex messages were distributed). 
4. HIV/SOA preventie methodieken heteroseksuele migrantenmannen (HIV/STI prevention programme for heterosexual migrant men)

- Goal: Promote safe sex practices among heterosexual migrant men from Muslim and Caribbean backgrounds.

- Method: Cultural- and gender- specific educational/intervention events for both groups.

5. Coffeeshops en Theehuizen Utrecht e.o. (Coffee-shops and teahouses in Utrecht)

- Goal: Improve safe sex practices among ethnic minorities.

- Method: STI and HIV education for migrant customers in coffee-shops and teahouses in Utrecht, especially Turkish and Moroccan migrants.

This large quantity of prevention programmes for ethnic minorities, such as those listed below, is due to an increase in the budget for this "risk-group" which occurred after the publication of the data in the 2005 RIVM report. In 2004, while presenting the prevention plan and finances for HIV and STI in the Netherlands, the minister of Health, Welfare and Sport referred to the data presented in the 2005 RIVM annual report. The STI AIDS Netherlands advisory report (the official document upon which the minister bases the prevention plan and finances) stated that the RIVM research indicated that among Surinamese, Antilleans, Cape Verdeans and Ghanaians there is "high-risk sexual behaviour", "a high number of sexual partners", "inconsistent condom use", "sexual activity in country of origin", and "mixing among various ethnic minority groups" (STI AIDS Netherlands, 2004 in Hoogervorst, 2004). Consequently the minister announced that 550,000 -Euro would be made available for the prevention programme for ethnic minorities, of which 150,000-Euro was be reallocated from both the youth prevention programme budget and the homosexual men prevention programme budget (the chronological discrepancy of the 2005 report being referenced in 2004 is due to publication lag, however the data was made available before publication of the official annual report).

Similarly, referencing the RIVM behavioural studies, various members of the Dutch parliament highlighted the increased risk of ethnic minorities, naming specifically Surinamese, Antillean and African populations and the supposed promiscuity and lack of safe sex practices and the risk this might pose to the general Dutch public. On January 27, 2006 an official question was submitted by parliament members inquiring whether the minister of Health, Welfare and Sport was aware of the RIVM city surveys among highrisk populations, and how he planned to prevent the spread of HIV from migrant groups to other populations (v. Tweede Kamer, Aanhangsel 1951). Again on December 8, 2008, parliament members submitted an official question asking the minister of Health, Welfare and Sport whether he was aware of the media reports stating that HIV/AIDS was a "big problem" within ethnic minority groups; and whether lack of testing and unsafe sex practices among migrant groups were a threat to public health in general (v. Tweede Kamer Aanhangsel 2635). These questions posed in parliament refer to supposed high-risk sexual behaviour of ethnic minorities and migrants in the Netherlands, and cite directly the work of the RIVM as the source of this information. These interactions illustrate the moments in time when the ethnic construct, produced in the work of the RIVM, enters the political and social sphere and very directly shapes the minds and institutions governing Dutch society. Simultaneously, further coevolution takes place through the popular media.

On December 6, 2008, the director of Stichting HIV Monitoring (Foundation HIV Monitoring), who is also an Amsterdam city council member, stated in an interview in the national newspaper NRC Handelsblad: "Migranten uit die landen komen naar
Nederland. Ze integreren in de Nederlands maatschappij. Ze vrijen met een autochtone vrouw. Zij raakt besmet. Daarna verspreid ook zij het virus. Noem het een bijeffect van de verbeterde intergratie [Migrants from those countries come to the Netherlands. They integrate into Dutch society. They have sex with a Dutch woman. She gets infected. Then she also spreads the virus. Call it a side effect of improved integration] (Bouma \& Müller, 2008). Similarly media reports can be found in other national Dutch newspapers. Reporting the results of the first RIVM Rotterdam city survey, the Algemeen Dagblad prints: "Het onderzoek toonde onder Kaapverdianen, Surinamers en Antillianen nauwelijks hiv-besmetting. Zij lopen echter wel een verhoogd risico omdat ze veel partners (tegelijkertijd) hebben en weinig condooms gebruiken" [The survey barely indicated hiv-infection among Cape Verdean, Surinamese and Antillean. They are high risk however, because they have many (simultaneous) partners and use few condoms] ("Helft verslaafden weet niet van hiv-besmetting; Rotterdam," 2005). Likewise, on January 25, 2006, the Algemeen Dagblad reported the results of the RIVM Amsterdam city survey and stated: "Het gevonden percentage geïnfecteerden was daarentegen laag: 1 procent van de Surinamers en Ghanezen en nul procent van de Antillianen. Wel vertoonden vooral de mannen riskant seksgedrag. Zo hadden ze verschillende seksuele partners en gebruikten ze niet vaak een condoom" [Prevalance was low, 1 percent of Surinames and zero percent among Ghanaians and Antilleans. However, especially men exhibited high risk behaviour. They had different sexual partners and often did not use a condom]("Zeven procent Amsterdamse prostituees besmet met hiv.," 2006).

It is here where the co-evolution on the ethnic construct can be illustrated. And so the construct evolves, now even more solidified and validated, through the realm of scientific research and professional practice to be operationalized further in politics and society. All the while the constructedness of this idea remains invisible, and the "knowledge" "gained" regarding the high risk sexual habit of ethnic minorities becomes common sense; a known fact in science, politics, practice and society.

\section{Conclusion}

The conventional account of this tale would suggest that the RIVM reports present objective scientific findings, new information on a factual reality. And as such, this new knowledge is enacted in politics and prevention practice and communicated to society through the media accordingly. This paper presents an alternative account, one where in co-evolution between the RIVM, Dutch politics, prevention practice and the media, ethnicity is constructed first in the work of the RIVM and consequently validated and solidified as it interacts in and with society and finally fed back to the scientific realm. Such co-evolution between scientific and professional practice and society allows socially constructed notions of ethnicity to be enacted in science and professional practice and treated as apolitical variables. Through these institutions, scientific and professional merit is then ascribed and factual knowledge is produced. Subsequently, these scientifically proven facts about ethnicity (and ethnic minorities) re-enter society where they further evolve and can perpetuate categorical systems of difference.

The epidemiological work of the RIVM on HIV and STI in The Netherlands to conduct serosurveillance and behavioural research among "migrants from areas with generalized HIV-epidemics", as advised by the RGO, has resulted in the materialization of a distinct ethnic construction, the high risk sexual ethnic other who is at heightened risk of HIV and who spreads HIV in the Netherlands through promiscuity and absent safe sex practices. And so ethnic minorities are constructed as sexually promiscuous, unsafe and, 
most importantly, different from the general Dutch population. As shown throughout this paper there are two specific mechanisms through which this is allowed. Firstly, the vague, inexact and multiform conceptualization and use of the concepts ethnicity and migrant. And secondly, the explanatory dominance of ethnicity, which allows any differences found to be explained in terms of differences in ethnicity. Together these mechanisms allow this particular sexualized construction of ethnicity to be self-validating. This construct is perpetually self-validating as it informs the methodological choices made by the RIVM such that behavioural studies almost always establish ethnic behavioural differences and so a categorical ethnic minority problem group is constructed within Dutch society. This research is disseminated widely through newspaper articles, dialogue in the Dutch House of Representatives and HIV/STI prevention practice, through which the construct is reaffirmed and ascribed validity. Knowledge of ethnic minorities' highrisk status and their sexual practices that lead to this become common, and so the construct is further operationalized in government budget planning and subsequent research programmes (Hoogervorst, 2004). This process is by no means innocent or without consequence: Common knowledge about ethnic minorities, such as that produced here, inform processes of social differentiation. These consequences must be problematized and responded to in future HIV and STI research in the Netherlands and beyond.

\section{Acknowledgements}

An earlier version of this paper was presented at the 2009 Society for Social Studies of Science (4S) Annual Meeting in Washington, DC. Steven Epstein is gratefully acknowledged for his comments on an earlier draft of this paper.

\section{References}

Berg, M., \& Mol, A. (1998). Differences in medicine: Unraveling practices, techniques, and bodies. Durham, NC: Duke University Press.

de Boer-van der Kolk, I. M., van de Laar, M. J. W., \& Op de Coul, E. L. M. (2009). Surveillance of sexual risk behavior within the STI surveillance system. Tijdschrift voor Gezondheidswetenschappen, . (1).

Bouma, J. D., \& Müller, J. (2008). Het kan iedereen overkomen; Aantal hivbesmettingen stijgt weer, ook onder hetero's. NRC Handelsblad, 6-7.

Cho, M. K. (2006). Racial and ethnic categories in biomedical research: there is no baby in the bathwater. Journal of Law Medicine E Ethics, 34(3), 497-499.

Collins, P. Y., von Unger, H., \& Armbrister, A. (2008). Church ladies, good girls, and locas: stigma and the intersection of gender, ethnicity, mental illness, and sexuality in relation to HIV risk. Social Science \& Medicine, 67(3), 389-397.

Epstein, S. (2007). Inclusion: The politics of difference in medical research. Chicago: University of Chicago Press.

Essed, P. (1991). Understanding everyday racism: An interdisciplinary theory. Newbury Park: Sage Publications.

Frank, R. (2007). What to make of it? The (Re)emergence of a biological conceptualization of race in health disparities research. Social Science \& Medicine, 64(10), 1977-1983.

Gilroy, P. (1987). There ain't no black in the Union Jack: The cultural politics of race and nation. London: Hutchinson.

Gravlee, C. C. (2009). How race becomes biology: embodiment of social inequality American Journal of Physical Anthropology, 139(1), 47-57.

Helft verslaafden weet niet van hiv-besmetting; Rotterdam. (2005). AD/ Algemeen Dagblad, 2.

Hoogervorst, H. (2004). Brief aan de Voorzitter van de Tweede Kamer. Preventieplan SOA en HIV in Nederland. Den Haag PG/ZP 2.537.024.

Hooks, B. (1992). Black looks: Race and representation. Boston, MA: South End Press.

Jasanoff, S., Markle, G. E., Petersen, J. C., \& Pinch, T. (Eds.). (1995). Handbook of science and technology studies. Thousand Oaks, Calif: Sage Publications.

Kaplan, J. B., \& Bennett, T. (2003). Use of race and ethnicity in biomedical publication. Jama-Journal of the American Medical Association, 289(20), 2709-2716.
Latour, B. (1988). The pasteurization of France. Cambridge, Mass: Harvard University Press.

Law, J. (1994). Organizing modernity. Oxford, UK; Cambridge, Mass., USA: Blackwell.

Law, J., \& Mol, A. (2002). Complexities: Social studies of knowledge practices. Durham, NC: Duke University Press.

Lee, C. (2009). Race" and "ethnicity" in biomedical research: how do scientists construct and explain differences in health? Social Science Er Medicine, 68(6), 1183-1190.

Meershoek, A., \& Krumeich, A. (2009). Multiculturalism and the construction of ethnic identities in Labour and health practices: avoiding the Culturalistic Fallacy in applied research. Health Care Analysis, 17(3), 173-197.

Meershoek, A., Krumeich, A., \& Vos, R. (2007). Judging without criteria? Sickness certification in Dutch disability schemes. Sociology of Health E' Illness, 29(4), 497-514.

Meershoek, A., Krumeich, A., \& Vos, R. (2011). The construction of ethnic differences in work incapacity risks: analysing ordering practices of physicians in the Netherlands. Social Science \& Medicine, 72(1), 15-22.

Moser, I. (2006). Disability and the promises of technology: technology, subjectivity and embodiment within an order of the normal. Information, Communication E Society, 9(3), 373-395.

National Institute for Public Health and the Environment RIVM. (2005a). HIVsurveys bij hoog-risicogroepen in Amsterdam 2003-2004. RIVM rapport 441100021 (p. 84 p.). Bilthoven: RIVM.

National Institute for Public Health and the Environment RIVM. (2005b). HIVsurveys bij hoog-risicogroepen in Rotterdam 2002-2003. RIVM rapport 441100019 (p. 95 p.). Bilthoven: RIVM

National Institute for Public Health and the Environment RIVM. (2006a). HIV and sexually transmitted infections in the Netherlands in 2005. RIVM report 441100024 (p. 163 p.). Bilthoven: RIVM.

National Institute for Public Health and the Environment RIVM. (2006b). HIVsurveys bij hoog-risicogroepen in Den Haag 2005. RIVM rapport 441100023 (p. 74 p.). Bilthoven: RIVM

National Institute for Public Health and the Environment RIVM. (2007a). Hiv-survey onder Surinamers, Antillianen en Kaapverdianen in Rotterdam 2006. EPI briefrapport 210261002 (p. 39 p.). Bilthoven: RIVM. [host].

National Institute for Public Health and the Environment RIVM. (2007b). Sexually transmitted infections in the Netherlands in 2006. RIVM rapport 210261003 (p. 122 p.). Bilthoven: RIVM.

National Institute for Public Health and the Environment RIVM. (2008). Sexually transmitted infections, including HIV, in the Netherlands in 2007. RIVM rapport 210261004 (p. 122 p.). Bilthoven: RIVM.

National Institute for Public Health and the Environment RIVM. (2009). Sexually transmitted infections, including HIV, in the Netherlands in 2008. RIVM rapport 210261005 (p. 122 p.). Bilthoven: RIVM.

Nationaal Onderzoek Multimedia. (2010). NOM print Monitor 2009I/2009II. Retrieved from. http://www.nommedia.nl/docs/BereikscijfersNPM2009-I2009-II.pdf.

Persson, A., \& Newman, C. (2008). Making monsters: heterosexuality, crime and race in recent Western media coverage of HIV. Sociology of Health and Illness, 30(4), 632-646.

RGO, R. v. G.. (2001). Advies HIV-surveillance in Nederland. Den Haag: Raad voor Gezondheidsonderzoek.

Schulz, A. J., \& Mullings, L. (2006). Gender, race, class, and health: Intersectional approaches. San Francisco, CA: Jossey-Bass.

Shim, J. K. (2002). Understanding the routinised inclusion of race, socioeconomic status and sex in epidemiology: the utility of concepts from technoscience studies. Sociology of Health E Illness, 24(2), 129-150.

Sinha, S., Curtis, K., Jayakody, A., Viner, R., \& Roberts, H. (2007). People make assumptions about our communities': sexual health amongst teenagers from black and minority ethnic backgrounds in East london. Ethnic Health, 12(5), 423-441.

Stillwaggon, E. (2006). AIDS and the ecology of poverty. Oxford; New York: Oxford University Press.

Tweede Kamer, v. Aanhangsel 2635 Vragen van het lid Arib (PvdA) aan de minister voor Volksgezondheid, Welzijn en Sport over het bericht dat gemiddeld $7 \%$ van Amsterdamse prostituees besmet blijkt te zijn met hiv. (Ingezonden 27 januari 2006).

Tweede Kamer, v. Aanhangsel 2635 Vragen van het leden Arib en Leerdam (beiden PvdA) aan de minister voor Volksgezondheid, Welzijn en Sport over het grote aantal HIV/Aids patiënten onder migrantengroupen. (Ingezonden 8 december 2008).

Vrolings, E., Gellissen, R., Jonkers, R., \& Schaalma, H. (2006). SOA en HIV/AIDSpreventie onder etnische minderheden in Nederland. Een kritische analyse van 'best practices' vanuit een evidence-based perspectief. Soa Aids Nederland.

Wyatt, G. E. (1991). Examining ethnicity versus race in AIDS related sex research. Social Science \& Medicine, 33(1), 37-45.

Zeven procent Amsterdamse prostituees besmet met hiv. (2006). AD/ Algemeen Dagblad, 9. 